Bulletin UASVM Agriculture 69(2)/2012

Print ISSN 1843-5246; Electronic ISSN 1843-5386

\title{
Improper Household Waste Disposal in Rural Territory. Case Study: Neamţ County, Romania
}

\section{Florin Constantin MIHAI}

\author{
Faculty of Geography and Geology, "Alexandru Ioan Cuza" University of Iaşi, \\ 35 B-dul Carol I, Nr. 20 A, RO-700505, Iasi, Romania; mihai.florin86@yahoo.com
}

\begin{abstract}
Open dumping of waste generated and uncollected is the most common option in waste management schemes from rural areas. Lack of sanitation services or rudimentary waste management systems favored this practice. This paper proposes a method to estimate the amounts of household waste uncontrolled disposed at local administrative unit level (commune) for 2003 and 2010. Based on estimating the amounts of waste generated and uncollected are introduced new indicators in the quantitative analysis taking into account the household waste composition, individual composting of biodegradable waste or recyclable waste from households for a more proper assessment of waste disposed. Usually household waste is disposed in various sites according to local geographical context such as open dumps on local roadsides, forest areas or on riverbanks. The indicators were calculated for each commune from the county that did not have access to sanitation services. Processed data were mapped, thematic maps outlining regional disparities existing between communes from county. Comparative analysis of the years 2003 (pre-accession period) and 2010 (post-accession) highlights the changes and difficulties to provide waste management facilities in rural territory.
\end{abstract}

Keywords: waste dumping, rural areas, diparities,waste management, waste indicators,

\section{INTRODUCTION}

EU acquis on municipal waste management imposes the promotion of best practices in this field conforming to the principle of waste hierarchy, landfilling being an undesirable solution. The aim of the waste hierarchy is to extract the maximum practical benefits from products and to generate the minimum amount of waste (Passarini et al.2011).Unfortunately, socioeconomic disparities in the EU-27 is reflected in waste management systems adopted by each country. (Mihai and Apostol,2012).

Landfill is still a basic solution in Romania the same as others new EU members.Mihai et al.(2012a,b) revealed that partially access of urban and rural population to sanitation services lead to uncontrolled disposal of waste. In this context, geographic demographic and socio-economic conditions play an important role in geographical distribution of rural dumpsites at local and regional scale (Mihai et al.2012c)

This paper aims to develop a methodology using new indicators which assess the vulnerability of rural territory to illegal dumping of household waste generated and uncollected from local population. Thus, this study does not include other similar waste streams from companies and public institutions, waste derived from demolition and construction or waste from agricultural origin (agricultural waste, sawdust, manure etc.).

This approach is applied at local scale to outlining on the one hand the disparities between communes of Neamt County, where poor waste management systems still prevail, and on the other hand,to highlight the role of geographical conditions in this field. 


\section{MATERIALS AND METHODS}

First, it carried out a database for the years 2003 and 2010 concerning the number of people for each commune of Neamţ County. Numbers of inhabitants of 2003 include data from population census in 2002 and for 2010 data were provided by National Statistics Institution.

Base map contains administrative limits of communes from 2007 (last update) which has been used for 2003 too. It should be noted that in period 2004-2006 new communes appeared in Neamţ County and furthermore Roznov commune was declared city in 2004.

Because of these changes at administrative territorial units (ATU), population at the commune level for 2003 was recalculated. This recalculation was based on population census from 2002, data being available at the village scale. In this way, it could achieve a correct recalculation of population from these communes using the same base map.

It has been determined for communes without access to sanitation services the amounts of waste generated and uncollected taking into account an rural average generation of waste $(0.3 \mathrm{~kg}$.inhab /day). Due to socio-economic conditions in this county, the value of this indicator is more appropriate than those provided in Regional waste management plan of North-East Region (2006) such as $0.4 \mathrm{~kg}$ per capita / day. According to this plan, it expects an annual increase $0.8 \%$ of the amount of household waste, thus, in 2010 , per capita waste generation indicator (Ig) has a value of $0.33 \mathrm{~kg} /$ per capita/day. This is an average value used in all geographic regions against existing disparities. The lack of relevant statistical databases and inappropriate weighing systems of waste collectors require the use of such indicators.

The amount of waste generated and uncollected $(\mathrm{Qwu})$ is calculated at commune level according to this formula : Qwu (t/yr) $=\mathrm{Pu} * \mathrm{Ig} * 365 / 1000$

$\mathrm{Pu}$ - population of commune unserved by sanitation services ( $\mathrm{nr}$ of inhab.)

$\mathrm{Ig}$ - per capita generation of household waste ( $0.3 \mathrm{~kg}$.inhab/day for 2003 - an average value)

In this study, population unserved $(\mathrm{Pu})$ coincides with total population of communes, because these calculations were made for localities without access to sanitation services in 2003 and 2010.Unfortunately there is no clear data at such level regarding the number of inhabitants connected to sanitation services for calculating this indicator for all communes. In most cases, although on paper the entire population is served, field observations highlights the fact that these communities are facing with illegal dumping.

Estimation the amounts of waste generated and uncollected allow an assessment of vulnerability to waste pollution (Mihai et al,2011). As regards rural territory, the situation is more complex because here comes the individual reuse or recovery in households of waste generated and uncollected. Particularly the biodegradable fraction of waste from food scraps that are reused in animal feeding (cats, dogs, pigs, poultry) or together with other agricultural waste as compost.

National literature does not come with precise data on individual recovery of waste in rural areas however its conclude that organic wastes are reused (Bularda,1992;Bold, 2003;). Furthermore, Regional waste management plan of Bucharest-Ilfov region (2006) mentions that organic waste is almost entirely used as food source for livestock or compost in rural areas. Field observations concerning rural dumpsites from Neamt county reveals a low share of household organic waste (food waste) but other fractions are present such as agricultural waste, manure or sawdust (Apostol and Mihai,2011).

On the other side, recyclables (paper/cardboard, glass, metal, wood, plastic) have a increasing share in rural territory due to easier flow of consumer goods since 1990. Therefore a part of these fractions are used in households (for fire wood and paper, glass and PET bottles for storage of different foodstuffs / drinks, etc.) but also these fractions are frequently 
disposed in open dumps.

In this context, to estimate the quantities of waste to be uncontrolled disposed (Qud) from amount of waste generated and uncollected (Qwu) it should be take into account the organic and recyclable fractions of waste that can be individually reused in households (Qrh indicator). In order to determine the amount of these fractions it needs to know the composition of household waste from rural areas. Unfortunately, in Romania there was no waste composition analysis (based on weighing the waste) in rural areas but only estimates made by waste operators. Waste composition of household waste from rural areas at NorthEast Region scale for 2003 shows a $62 \%$ share of biodegradable waste (Sbw) and for recyclable waste (Srw) 23.5 \%.(REPA Bacău,2006). For the year 2010 it has been used data from the project Balkwaste - Life Project (2010) which studied the analysis of the composition of household waste (weigh-sorting) from all 6 counties of North-East Region. Thus, in gross composition of household waste for Neamt County the biodegradable and recyclable fractions have shares of 65.4 respectively $22.2 \%$ (Balkwaste, 2010).

In order to determine the amounts of biodegradable (Qbw) and recyclable (Qrw) fractions from total amount of waste generated and uncollected for a particular year at commune level is need to applied these formulas:

Qbw (t/yr) = Qwu (t/yr.) * Sbw (\%), Sbw - share of biodegradable (\%) in waste composition for year 2003 and 2010 in this study;

$\operatorname{Qrw}_{\mathrm{yr}}(\mathrm{t} / \mathrm{yr})=\mathrm{Qwu}^{*} \mathrm{Srw}_{\mathrm{yr}}(\%)$, Srw - share $(\%)$ of recyclables (paper/cardboard, glass, metal, wood, plastic) in waste composition for year 2003 and 2010 in this study;

Potential reuse and recovery of waste in individual households (Qrh) is considered to be $70 \%$ for biodegradable waste (food waste) used mainly as food for pets and partially for obtaining a compost and 10\% for the recyclables fractions. However, packaging waste in recent years have invaded rural areas and lack of waste management systems have led to their disposal in open dumps or on riverbanks especially in mountain regions. So Qrh is estimated by applying the following weightings : Orh $=0.7 * \mathrm{Qbw}+0.1 * \mathrm{Qr}$

Finally, Qud can be calculated : Qud t/yr $=$ Qwu - Qrh. Uncontrolled disposal of waste (Qud) takes place either in open dumps in various sites (river banks, roadsides, the back of gardens, forest areas) or by uncontrolled burning.

In order to illustrate these calculations Tamaseni commune is chosen as model for years 2003 and 2010.This commune did not have access to sanitation services so total population of this commune represents the $\mathrm{Pu}$ indicator. Qud indicator ( $2003 \& 2010$ ) it is estimated based on following calculations:

$$
\begin{aligned}
& \mathrm{Qwu}_{2003}=8263 * 0.3 * 365 / 1000=904.7985 \mathrm{t} / \mathrm{yr} \\
& \mathrm{Qwu}_{2010}=9391 * 0.33 * 365 / 1000=1131.146 \mathrm{t} / \mathrm{yr} \\
& \mathrm{Qbw}_{2003}=904.7985 * 62 / 100=560.9751 \mathrm{t} / \mathrm{yr} \\
& \mathrm{Qbw}_{2010}=1131.146 * 65.4 / 100=739.7695 \mathrm{t} / \mathrm{yr} \\
& \mathrm{Qrw}_{2003}=904.7985 * 23.5 / 100=212.6276 \\
& \mathrm{Qrw}_{2010}=1131.146 * 22.2 / 100=251.1144 \\
& \mathrm{Qrh}_{2003}=0.7 * 560.9751+0.1 * 212.6276=413.9453 \\
& \mathrm{Qrh}_{2010}=0.7 * 1131.146+0.1 * 251.1144=542.9501 \\
& \mathrm{Qud}_{2003}=904.7985-413.9453=490.8532 \mathrm{t} / \mathrm{yr} \\
& \mathrm{Qud}_{2010}=1131.146-542.9501=588.1959 \mathrm{t} / \mathrm{yr}
\end{aligned}
$$

These model was applied for each commune without access to sanitation services in Neamt county for 2003 and 2010. After calculating the final indicator (Qud) it conducted two thematic maps of geographical distribution at commune level of this indicator. Thematic maps were used as method of spatial distribution proportional circles for absolute values. 


\section{RESULTS AND DISCUSSIONS}

In 2003, sanitation services in rural areas generally covered localities in the proximity of cities such as Târgu Neamt (Agapia, Băltătesti, Vânători-Neamt) and Piatra Neamt (Alexandru cel Bun, Gârcina, Dumbrava Rosie, Săvinesti, Girov, about 27000 residents served). However, it should be noted that these services rarely cover the entire population, furthermore, these services are temporary in the period 2003-2009 for this communes. Sanitation services of local authorities do not provide regular waste collection services, waste generated were often collected and disposed in open dumps, their location being established by local councils. Thus, open dumping prevailed in most villages in the Subcarpathian and plateau regions, even in villages connected to waste collection services.

In this context high values of Qud indicator (300-600 t/yr) overlaps on regions with large population from Bistrita valley (in subcarphatian sector, south of Piatra Neamt city),rural communities in the proximity of Roman city and some localities of Neamt depression (Grumăzesti, Petricani).

Demographic implications are obvious in such an analysis also influenced by socioeconomic conditions and geographical location in relation to cities, which play the role of polarizing centers at regional or local scale.

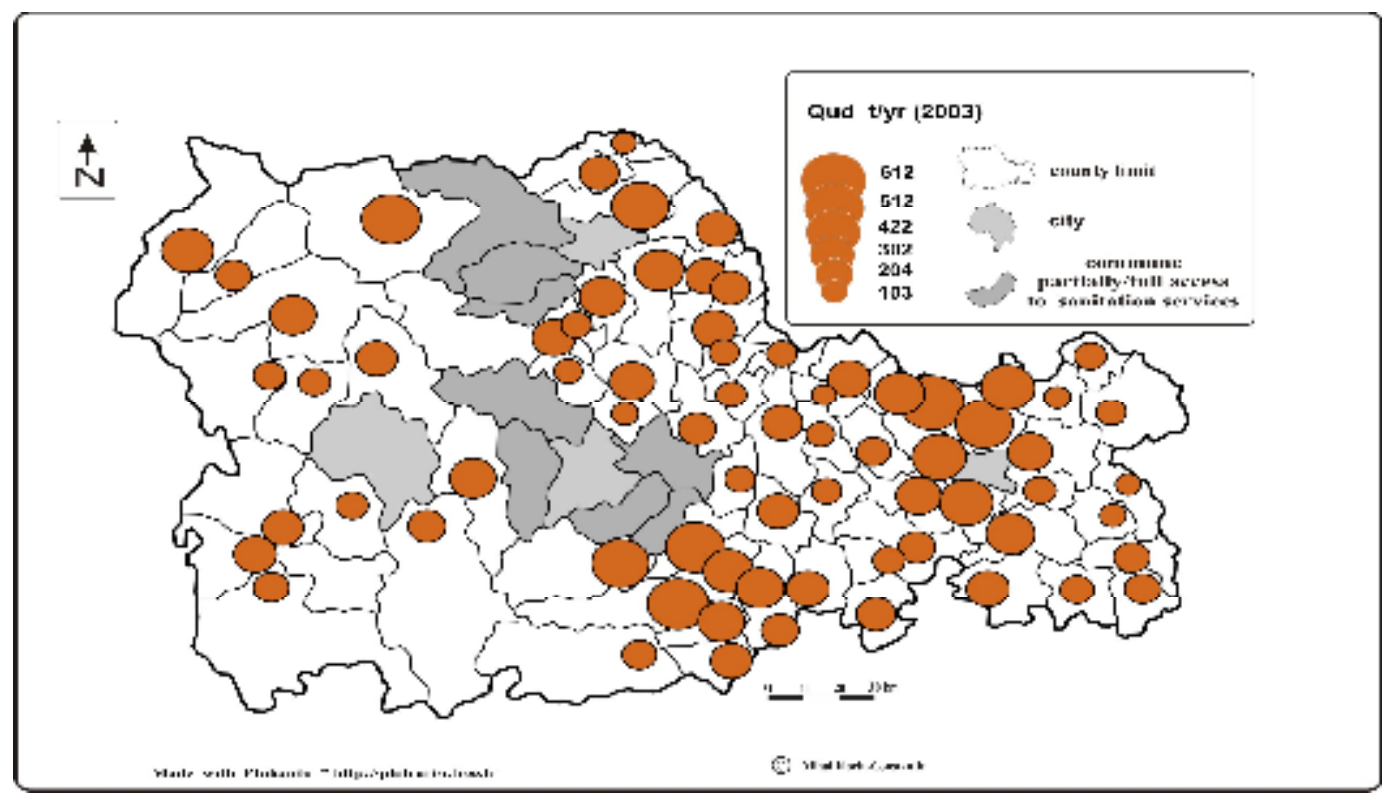

Fig. 1. Geographical distribution of Qdu indicator in 2003

The values of Qud are higher in some communities in the mountain region of the county (western half) than the less populated eastern half (communes from central and southeastern of county) although the analysis performed by Mihai et al. (2012 b) concerning the areas of rural dumpsites of waste in 2009 were lower. This again highlights the fact that in mountain regions wastes were disposed in rivers or on their banks, these sites being temporary due to frequent summer floods. Following July 16,2009 along the closure of rural dumpsites, local authorities were obliged to provide waste collection facilities, waste collected being transported to urban landfills from Târgu Neamt and Roman. 


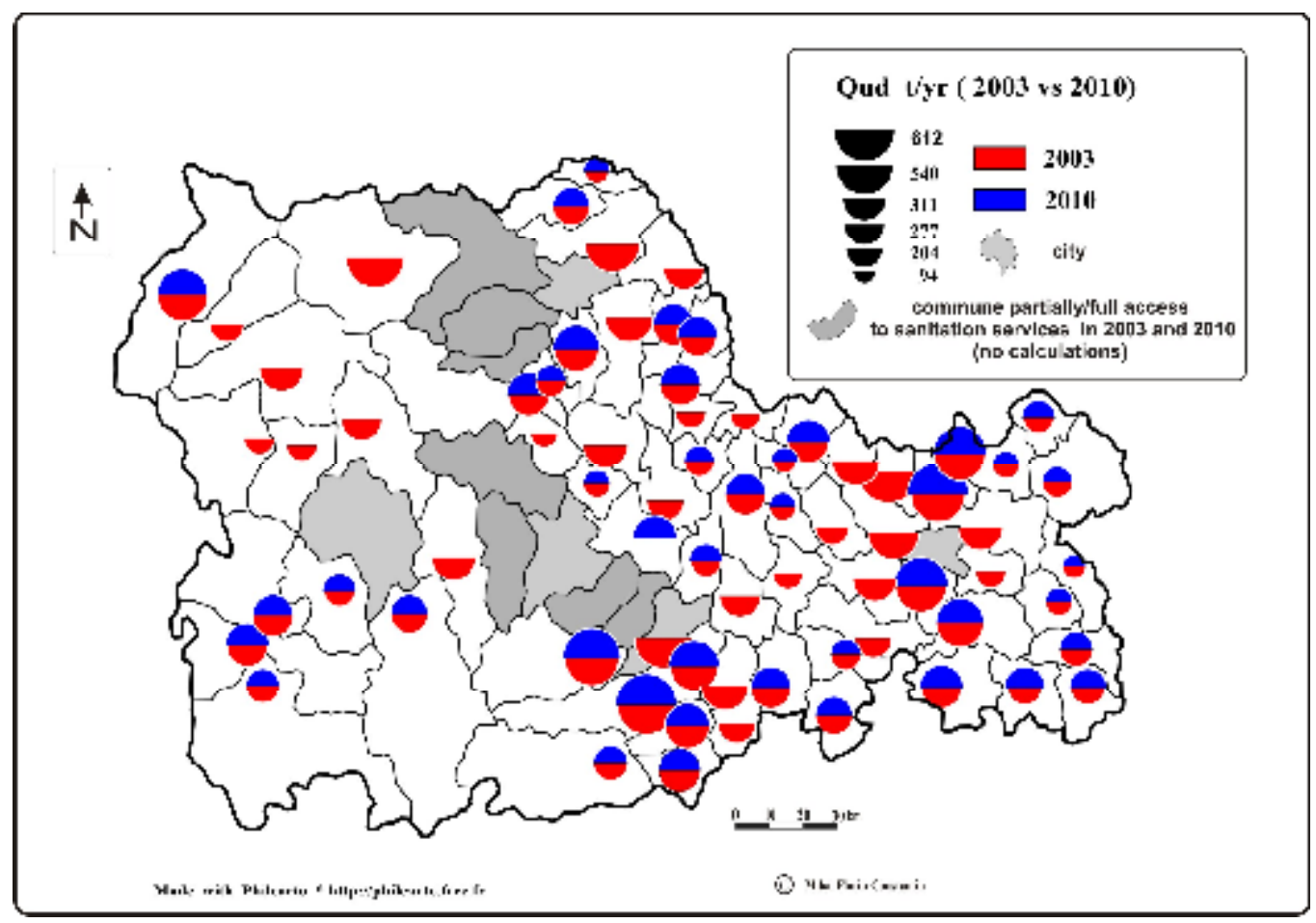

Fig. 2. Comparative analysis of Qud indicator 2003 vs 2010

Sanitation services were extended in 2010 compared to 2003 but still several communes were not covered by these services (only for these communes. Moreover, mixed waste collection prevails and several villages is still facing with illegal dumping. Comparative analysis between 2003-2010 shows that on the one hand the extension of sanitation services limits the illegal dumping and on the other hand Qud indicator keeps the same values with a slight upward trend in 2010 for settlements without sanitation services. Vulnerability to uncontrolled disposal of waste in rivers or on their banks is higher in touristic region of Bicaz valley (including following communes:Dămuc, Bicaz-Chei, Bicazu-Ardealean, Tasca) also for Tarcău commune or tributaries of rivers Bistrita from subcarpathian sector on the territory of Piatra Soimului and Borlesti communes.

Communes of southern, central and southeastern of county are exposed to open dumping as well certain populated communes without sanitation services (Doljesti, Tămăseni)

In mountainous regions and subcarpathian depressions, the open dumps on riverbanks or floodplains are still present. Waste burning often in inappropriate places (behind households, near rivers banks, etc.) becoming an alternative solution for open dumping due to controls carried out by commissioners of National Environment Guard after the deadline (July 16, 2009) for closure of rural dumpsites.

The implementation of selective waste collection systems as well as facilities for the composting of biodegradable waste is required. It should be noted that although it was performed a traditional composting of biodegradable fraction (most of them from agricultural source and partially from food waste) its performance is rather low due to inadequate treatment. In this regard, the new waste management systems stipulate facilities for collection and individual composting of biodegradable waste from houses area of cities but especially for rural areas with high population density. Practice guidelines for individual composting are currently promoted by local environmental authorities. 


\section{CONCLUSION}

Calculating Qud indicator offers for the first time a quantitative estimation of waste that can be disposed by uncontrolled burning or open dumping in rural areas at commune level in Romania. Also, for a more pertinent estimation is weighted on one side the amount of biodegradable waste that are reused in households and on other side a part of recyclables from total waste generated and uncollected (Qwu). These weightings take into account the household waste composition, calculating the Qrh indicator. Although these values are indicative, it is a first step to the development of a methodology for assessing the vulnerability of rural areas to waste dumping. Thematic maps highlights local disparities existing in various geographical conditions of Neamt county. In the future, improvement of data on waste composition (by measurements in rural areas), population served/unserved by sanitation services (accurate data), per capita generation of household waste (weighed values) and achievement of geographic database at commune level will allow gradually improve of results, creating an important tool in planning for waste management facilities in rural territory.

\section{REFERENCES}

1. Apostol,L. and F.C.Mihai (2011). The process of closing down rural landfills Case study : Neamt county,Present Evironment and Sustainable Development 5(2) :167- 174

2. Bold,O.V. and G.A.Mărăcineanu (2003). Managementul deşeurilor solide urbane şi industriale,ed.Matrix Rom,Bucureşti

3. Bularda,G.,D.C.Bularda, T.Catrinescu (1992). Reziduuri menajere,stradale si industriale,ed. Tehnica,Bucuresti

4. Mihai, F.C., A.A.Ghiurcă, A.Lămăşanu (2011). Estimation of urban waste generated and uncollected in Romania, Analele Universitati Oradea Fascicula:Protectia Mediului, 17(2) :719-724

5. Mihai, F.C . and L. Apostol (2012). Disparities in municipal waste management across EU-27. A geographical approach, Present Environement and Sustainable Development, 6 (1):169-180

6. Mihai,F.C.,A.Lămăşanu and L.Apostol (2012a). Regional disparities in urban population access to sanitation services.Case study:Romania.Mediterranean Journal of Social Sciences,Special issue, 3(6): 273-279

7. Mihai,F.C., L.Apostol, A.Lămăşanu and A.A.Ghiurcă (2012b). Spatiotemporal analysis of Romania's rural population access to sanitation services in the context of EU accession,Proc. $12^{\text {th }}$ International Multidisciplinary Scientific GeoConference SGEM 5: 787-792

8. Mihai,F.C., L.Apostol, A.A.Ghiurcă, A.Lămăşanu and A.Bănica (2012c). Geographical distribution of rural dumpsites in North-East Region from Romania, Proc. $12^{\text {th }}$ International Multidisciplinary Scientific GeoConference SGEM 5:447-452

9. Passarini,F., I.Vassura, F.Monti, L.Morselli. and B.Villani (2011). Indicators of waste management efficiency related to different territorial conditions, Waste Management, 31:785-792

10.***,Romania,Regional Environment Protection Agency of Bacau (2006).Regional waste management plan in North-East Region (http://www.anpm.ro/articole/cadrul_general-140)

11.***,Romania,Regional Environment Protection Agency of Bucharest (2006).Regional waste management plan in Bucharest - Ilfov Region (http://www.anpm.ro/articole/cadrul_general-140)

12.***,Balkwaste- Life Project (2010) Final report on municipal solid waste composition in Romania and Bulgaria ( http://www.balkwaste.eu/?lang=ro ) 